\title{
「紙とパルプの科学」山内龍男著 京都大学学術出版会
}

ISBN4-87698-818-8

東京大学大学院 農学生命科学研究科 生物材料科学専攻 江 前 敏 晴

「紙とパルプの科学」と題する山内龍男先生 (京都大学 大学院農学研究科森林科学専攻)の著書が京都大学学術出 版会からこの 2006 年 11 月に出版された。紙パルプ分野だ けに焦点を当てた教科書的な本は「パルプ打よび紙」(1991 年刊、文永堂出版)が最後で、既に絶版となっているため、 紙の研究や利用に携わる若手の技術者にとっては待望の書 である。目次は、紙パルプとは/パルプ用材としての木材 の特徵/パルプの製造/パルプの漂白/環境および公害対策 /紙料の調成/抄紙工程/紙の加工/紙の基本的特性值とそ の構造/紙の物性/紙の用途としての印刷、コピーと印字/ 和紙の特徴、となっている。内容の難易については、大学 の学部生対象の講義をまとめられたと著者から伺っている ように、幅広い話題を扱っているにもかかわらず基本を しっかり抑えて解説されている。またバイオマス利用や環 境問題にも言及されており、非木材パルプ化の問題点を指 摘した上で木材がもっともパルプ化に適するという論理的 な見解も説得力がある。歴史的に見てバイオマス資源を最 も有効に利用してきた紙パルプ産業への愛着と自負を随所 に感じさせてくれる。ご専門である紙の物性については、 熱画像法や破壊鞀性といった新しい手法やアプローチの紹 介があるのもこれまでの教科書にはなかった特徴である。 コラム記事では、襖や障子の話、表具師の話など、和紙に も造詣の深い著者の一面も坦間見ることができる。紙は製 造プロセスの中で原料側から見れば最終製品であるが、紙

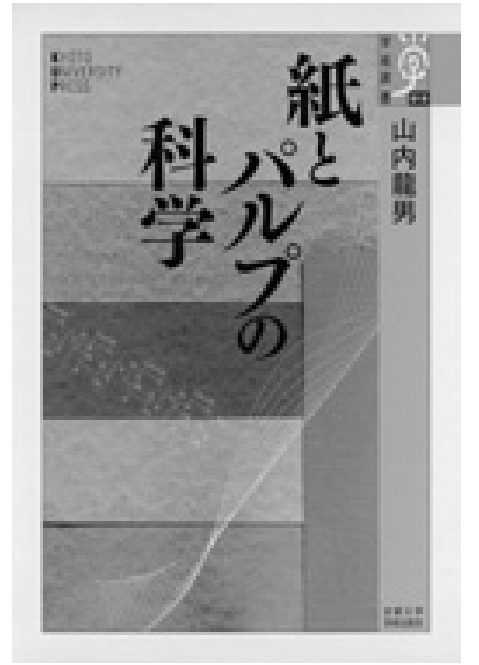

を応用した技術や製品を考えれば基本的な素材とも言える。 このような応用には素材の物性の把握は欠かせない。著者 があとがきで「再度日本でも紙・パルプ学(特に紙科学)を 復活させたいとの思い」と書かれたのも単なる哀愁では決 してないことが伝わってくる。

ASIN : 4876988188、191 ページ、サイズ：19×13cm、1,575 円(税込)

発行所：京都大学学術出版会 電話 075-761-6182 